\section{Poročilo predsednika DAHŠ Slovenije za obdobje maj 1999-september 2001}

\section{URADNE ZADEVE - DELOVANJE IN PREDSTAVITEV}

Registracija društva. Prva naloga, ki nam je ostala še od prejšnjega vodstva, je bila registracija društva v skladu z zakonom o društvih. Da se je postopek srečno končal, čeprav so medtem potekli že vsi predpisani roki, se imamo najbolj zahvaliti tajniku društva mag. Hriberšku, ki je vse potrebno opravil vestno in hitro. Tako je bilo društvo dne 1. 2. 2000 vpisano v register društev pri Ministrstvu za notranje zadeve.

Prepoznainost vjarmosti. Že na več sejah UO in uredniškega odbora revije so člani tu in tam omenili, da bi bilo treba več storiti za prepoznavnost društva v javnosti. Zlasti je na to opozarjal član uredniškega odbora revije Keria dr. Stanko Kokole. Zato smo zasnovali logotip društva, ki ga od lanskega poletja uporabljamo v glavi uradnih dopisov in vabil. Novi logotip smo uporabili tudi na novem žigu društva, ki je bil izdelan spomladi 2000. Posebej smo pazili na to, da novi žig ustreza določilom društvenega statuta.

$\mathrm{V}$ podatkovno bazo nas je uvrstila družba Mediana, ki se ukvarja z raziskovanjem javnega mnenja. Odtlej res dobivamo več pošte: največ je sicer reklam, a vmes je tudi kakšno koristno obvestilo ali zanimiva ponudba.

JKmalu po začetku mandata smo začeli članstvo društva obveščati o društveni dejavnosti tudi po elek- tronski pošti. Ker ima elektronski naslov skoraj dve tretjini članov, nam tovrstno obveščanje prihrani na leto najmanj 15.000 SIT za poštnino.

Od lani ima društvo svojo spletno stran, na kateri objavlja poročila o tem, kaj dela, in sporočila o tem, kaj bo delalo. Spletna stran je vpisana tudi na slovenskem spletnem iskalniku Mat kurja, tako da jo je zelo lahko najti. Posebej se zahvaljujemo Filozofski fakulteti, ki nam je odstopila prostor na svojem strežniku v okviru prostora za spletno stran $\mathrm{Od}$ delka za klasično filologijo.

Na strežniku Filozofske fakultete $f f s l$ je dobila prostor tudi spletna stran revije Keria. Na njej sproti objavljamo podatke o številkah, ki izhajajo. Poleg kazala si lahko obiskovalci spletne strani preberejo tudi povzetke znanstvenih prispevkov v tujem jeziku. Dejstvo, da ima revija svojo spletno stran, je bilo odločilno za to, da nam je Urad za znanost Ministrstva za šolstvo, znanost in šport letos prvič odobril denarno podporo, ki je bistveno izboljšala denarno stanje društva.

Letos spomladi se je uspešno končalo prizadevanje za ustanovitev lastne internetne diskusijske skupine. Zamisel izvira od mag. Mirana Špeliča, ki je imel nekaj podobnega $v$ mislih že pred leti. Na predlog Davida Movrina smo diskusijski skupini dali ime Agora, pri čemer je zadnji znak že del elektronskega naslova. Temu se ni bilo mogoče izogniti med drugim zato, ker v Franciji že obstaja diskusijska skupina $z$ enakim imenom. Zahvalo za posredovanje 
dolgujemo dr. Miranu Hladniku z Oddelka za slavistiko FF in Inštitutu Jožef Stefan, ki nam je dal prostor na strežniku. Skupina je v začetku delovala zelo živahno, prestala je tudi prve težave $\mathrm{z}$ virusom, ki se je vtihotapil v eno izmed sporočil. Razprave $\mathrm{v}$ diskusijski skupini so bile $\mathrm{v}$ prvih nekaj mesecih zelo raznolike, toda $v$ zadnjem času je vidno opešala, tako da v dopisovanju sodelujemo bolj ali manj samo trije člani skupine. Ćlovek si ne more kaj, da tega ne bi globoko obžaloval.

Pridobivanje novih članov. V zvezi s postopkom za registracijo smo na seji UO 13. 6. 2000 sklenili pregledati in posodobiti seznam članov društva. Tega smo se lotili septembra 2000, nastal je seznam članstva, ki temelji na pristopnih izjavah. Pristopno izjavo je izpolnilo tudi precej novih članov, predvsem tistih, ki so v zadnjih desetih letih končali študij in se vmes niso uradno včlanili. Po najnovejšem seznamu šteje društvo danes 88 članov v domovini in 12 v tujini; tem lahko dodamo še številne člane študentske sekcije društva. V prihodnjih letih bi bilo najbrž treba poskrbeti za bolj tekoč prehod članstva iz študentske sekcije med redne člane. Prav pri pregledu članstva, na podlagi katerega smo začeli pridobivati nove člane, smo ugotovili, da med člani društva ni nekaterih diplomantov latinščine ali grščine, ki so med študijem veliko delovali v okviru društva, a se po diplomi niso uradno včlanili med redne člane, tako da je društvo izgubilo stik z njimi.

Blagajniško poslovanje. Septembra
2000 smo po zaslugi iznajdljivega društvenega blagajnika dr. Marka Marinčiča posodobili blagajniško poslovanje tako, da lahko društvo vse bančne posle ureja po internetu. To se zlasti pozna pri nakazovanju honorarjev, ki zdaj poteka dosti hitreje kot prej, ko je bilo povezano z zamudnim izpolnjevanjem obrazcev in čakanjem v vrsti pred bančnim okencem.

\section{Revija KERA}

O reviji Keria v tem poročilu ne bomo veliko govorili, saj jo poznate vsi, ki jo (tudi zdajle) berete, in gotovo ves čas sami presojate, kako se razvija.

Omenimo samo, da dobiva revija denarna sredstva za izhajanje iz naslednjih virov:

- subvencija Ministrstva za kulturo RS;

- subvencija Urada za šolstvo pri Ministrstvu za šolstvo, znanost in šport; - subvencija Urada za znanost pri Ministrstvu za šolstvo, znanost in šport; - naročnina (društveni člani, zunanji naročniki);

- dohodki iz proste prodaje;

- prodaja oglaševalnega prostora v reviji.

Od 1. številke II. letnika je založništvo prevzela založba ZRC SAZU: z njimi sodelujemo dobro in trudimo se, da bi bilo v novih številkah karseda malo napak. Delo revije je bilo predstavljeno na dveh tiskovnih konferencah (maj 1999, organizator DAHŠ, in december 2000, organizator Založba ZRC SAZU). Revija je bila predstavljena tudi s člankom v Književnih listih in aprila 2001 na 
Televiziji Slovenija v oddaji Humanistika. Začeli smo tudi domačo in mednarodno izmenjavo, a tu se bo dalo še veliko izboljšati.

Število sodelavcev revije je že preseglo 30 . Čeprav smo se sprva bali, da bo to nekakšna interna revija Oddelka za klasično filologijo FF, nam je vmes uspelo pridobiti veliko sodelavcev od drugod. Za naslednjo številko se obetajo tudi prispevki iz tujine. Na to smo lahko ponosni, saj kaže, da ima slovenska klasična filologija vendarle več podpore, kakor se je zdelo na začetku.

$V$ dejavnost društva spada - $v$ sodelovanju s študentsko sekcijo - tudi prevod knjige Klasična retorika in njena krščanska in posvetna tradicija od antike do danes Georgea Kennedyja, ki smo jo izdali v sodelovanju $\mathrm{z}$ založbo ZRC SAZU. Zanjo nam je uspelo pri Ministrstvu za kulturo pridobiti izjemno visoko subvencijo, $k i$ je skoraj v celoti pokrila avtorske honorarje in omogočila, da se bo knjiga prodajala po za naše razmere dokaj znosni ceni.

\section{PRIREDITVE}

Predavanjav (so)organizaciji društva. Kot je navada ves čas od ustanovitve društva, smo tudi v zadnjih dveh letih poskrbeli za nekaj predavanj, na katera so bili vabljeni člani društva. Predavanj ni bilo prav veliko. Društvo samo je priredilo dve predavanji tujih predavateljev, večkratje vabilo svoje člane na predavanja, ki so jih prirejali drugi.

- Prvo izmed predavanj je bilo 25. 5 . 2000 v soorganizaciji z ZRC SAZU. Predaval je dr. Christopher Celen- za, strokovni sodelavec Centra za italijanske renesančne študije Harvardske univerze v Firencah (Pozna anti$k a$ in firenški platonizem: poplotinski Marcilio Ficino);

- 12. 12.2000 je predaval gost iz Zagreba dr. Dubravko Škiljan (Tipologija Herodotovih diskurzov).

Clane društva smo vabili tudi na nekatera druga predavanja:

- januarja 2000 je na Pravni fakulteti v okviru Svobodne katedre predaval dr. Vladimir Simić (Naravno pravo pri Homerju);

- 20. 12. 2000 je na FF gostoval dr. Franz Römer z Univerze na Dunaju (Pesniški panegirik na Habsburžane v 16. stoletju);

- 10.4. 2001 je na Oddelku za umetnostno zgodovino FF predaval dr. Stanko Kokole (Zgodnjerenesančni liki poganskih bogov med besedo in podobo).

Žal je treba tukaj pripomniti, da je udeležba na tovrstnih predavanjih vsaj kar zadeva člane društva - razmeroma slaba. Če ne štejemo študentov in članov Oddelka za klasično filologijo (ki bi se predavanja najbrž udeležili tudi brez društvenega vabila), se predavanja redkokdaj udeležijo več kot dva ali trije člani društva, tako da uspeh in odmev predavanja navadno ne odtehtata dela pri organizaciji. Dodatna težava pri predavanjih je tudi, da je teže dobiti predavatelja za soboto, se pravi za dan, ko bi imeli čas tudi člani društva zunaj FF.

\section{Recital prevodov antičnih epigramov} (več o tem v poročilu študentske sekcije): na Gimnaziji Poljane, v klubu Drame, na slovenski gimnaziji v Tr- 
stu. Med člani študentske sekcije imata veliko zaslug za predstavitve Nada Grošelj in David Movrin.

Posvetovanje o prevajanju antičnih in srednjeveških besedil. Lani smo se odločili uresničiti pobudo, ki jo je že pred leti dal dr. Kalan, in smo 9.9. 2000 priredili posvetovanje o prevajanju antičnih in srednjeveških besedil. Čeprav posvetovanja nismo obešali na veliki zvon - a najbrž bi ga morali - je prispevke prijavilo 12 referentov, večina jih je tudi res nastopila. Posvetovanje smo priredili $v$ dvorani Svetovnega slovenskega kongresa, ki nam je prostore po posredovanju podpredsednika društva mag. Braneta Senegačnika brezplačno prepustil v uporabo. Zato se zahvaljujemo podpredsedniku SSK, g. Francu Feltrinu. Zanimanja med člani društva je bilo toliko, da je bila dvorana skoraj premajhna, in kar žal nam je bilo, da je za razpravo ostalo le malo časa. A ker so prispevki objavljeni v drugi lanski številki revije Keria, se bo razprava gotovo lahko nadaljevala na kakšnem podobnem posvetovanju drugič.

Didaktični kolokvij. Lani je društvo obudilo tudi staro navado prirejati didaktične kolokvije za svoje člane. Udeležba na didaktičnem kolokviju (okrog 25 obiskovalcev), ki je bil 25. 11. 2000 v dvorani Društva slovenskih pisateljevv Ljubljani, je bila glede na dejstvo, da se latinščina in grščina pri nas vendarle poučujeta na razmeroma malo šolah, dobra in tudi razprava je prinesla veliko novega. Del prispevkov s tega kolokvija lahko beremo v prvi letošnji številki revije Keria.
Pogovor o klasični gimnaziji in klasični izobrazbi. Marca letos smo svoje člane povabili na pogovor $z$ akademikom dr. Gantarjem o klasični gimnaziji in klasični izobrazbi, ki je potekal $v$ Klubu Nove revije. Na pogovor je prišlo toliko članov društva, da so v klubu komaj zaprli vrata.

Ekskurzije. Tudi v preteklem mandatu je društvo organiziralo za svoje člane dve ekskurziji. Prva je bila 25. 9. 1999 na Gospo Sveto in Štalenško goro, druga 21. 10. 2000 po antičnih najdiščih na Primorskem. Obe ekskurziji sta bili za člane društva brezplačni, obakrat je ekskurzijo vodila arheologinja Katarina Batagelj. Prve ekskurzije se je udeležilo 31 članov društva in članov študentske sekcije. Program druge ekskurzije je obsegal predvsem najdišča, ki jih večina članov društva že pozna, zato je bila udeležba na drugi ekskurziji nekoliko slabša; poleg študentov Oddelka za klasično filologijo se je je udeležilo le 5 članov društva.

Festival vzgoje in izobraževanja v Celju. Na vabilo za udeležbo na Festivalu vzgoje in izobraževanja, ki nam ga je poslal organizator Zavod RS za šolstvo, se je odzvala študentska sekcija. Vodstvo društva je poskrbelo edino za prevoz.

\section{TEKMOVANJA}

Državno tekmovanje v znanju latinščine. Predlanskega tekmovanja, ki smo ga izvedli 6. 5. 2000, se je udeležilo 49 dijakov, prišli so $s 6$ šol (Gimnazija Poljane, Šubičeva gimnazija, I. Gimnazija Celje, I. Gimnazija Maribor, Škofijska klasična gimnazija 
Ljubljana, Škofijska klasična gimnazija Vipava). Lani smo se hoteli izogniti časovni stiski, povezani s podelitvami nagrad na skupni prireditvi, ki jo organizira Društvo za tuje jezike, zato smo tekmovanje priredili nekoliko prej in se sprijazniti $z$ dejstvom, da se bo križalo $z$ nekaterimi drugimi tekmovanji: bilo je 7. 4 . 2001. Žal smo morali z veliko zaskrbljenostjo ugotoviti, da je bila udeležba na tekmovanju 2001 bistveno slabša kot leto prej, saj so sodelovali samo dijaki treh šol (I. Gimnazija Maribor, Škofijska klasična gimnazija Ljubljana, Škofijska klasična gimnazija Vipava).

Ker je leta 2000 Ministrstvo za šolstvo in šport poostrilo merila za organizacijo državnih tekmovanj in $z$ njimi povezano dodeljevanje subvencij, je bilo treba sestaviti pravilnik tekmovanja in imenovati tekmovalni odbor. Za pravilnik je poskrbela Katja Pavlič Škerjanc, prevzela je tudi funkcijo koordinatorja tekmovanja in predsednice tekmovalnega odbora, tega poleg nje sestavljata še Breda Čop in Ralph Prausmüller. Naloge za tekmovanje je predlani sestavila Katja Pavlič Škerjanc in lani Breda Čop, medtem ko je popravljanje in ocenjevanje nalog obakrat v celoti opravila Breda Čop; obe si zato zaslužita posebno zahvalo. Pri nadzoru tekmovalcev so tako predlani kot lani sodelovali člani študentske sekcije društva: na tekmovanju 2000 so pomagale Nina Vuk, Kristina Tomc in Neža Vilhelm, na tekmovanju 2000 Nina Vuk in Matevž Zupančič, za kar se vsem lepo zahvaljujemo.
Če se bo pouk grščine v prihodnjih letih razširil na več šol po Sloveniji, bi kazalo pomisliti tudi na državno tekmovanje v znanju grščine. Pri tem ni nujno, da bi predpisana snov zajemala maturitetni modul, zadostovalo bi konec koncev tudi kakšno leto in pol učenja grščine.

Mednarodno tekmovanje Dediščina antike v evropski kulturi. Jeseni 2000 so nam $\mathrm{z}$ Univerze v Solunu poslali vabilo na vseevropsko tekmovanje Dedišcina antike $v$ europski kulturi. $\mathrm{K}$ sodelovanju so bili vabljeni študentje klasične filologije in dijaki, ki se učijo klasične jezike. Najboljša prispevka bi bila predstavljena na sklepni prireditvi na solunski univerzi in bi bila denarno nagrajena. Žal na to vabilo kljub visokim nagradam, za katere so bila sredstva zagotovljena, ni bilo nobenega odziva ne med srednješolci ne med študenti, čeprav smo razpis poslali na vse slovenske gimnazije, kjer se poučuje latinščina, in o njem obvestili tudi študente.

\section{FINANCIRANJE DEJAVNOSTI}

Podobno kot v prejšnjih letih je bila najzanesljivejši vir financiranja članarina, ki jo redno plačuje večina članov društva. Poleg tega smo v zadnjih dveh letih uspešno kandidirali na razpisih Ministrstva za šolstvo (zdaj Urada za znanost pri MŠZŠ) in Ministrstva za kulturo, čigar naklonjenost tukaj omenjamo s posebno hvaležnostjo.

\section{Mednarodno sodelovanje} $\mathrm{V}$ mednarodnem sodelovanju nam ni teklo vse po načrtih, poročilo zajema bolj podatke o tem, česa nismo 
naredili, a iskreno upamo, da bo v naslednjih letih kaj bolje.

Sodelovanje $z$ delovno skupnostjo štajerskih filologov. Plod osebnega prizadevanja nekdanjega predsednika društva Martina Benedika so bili dokaj živahni stiki z delovno skupnostjo štajerskih filologov v Gradcu, ki jo vodi $g$. Wolfram Liebenwein. Stike smo skušali ohraniti, a na pobude $z$ naše strani $v$ teh dveh letih ni bilo nobenega odgovora, tako da ne vemo, kako bo vnaprej. Načrtovali smo skupno ekskurzijo, vse skupaj je ostalo na ravni načrtov.

Colloquium didacticum classicum. Člani društva, ki so bili v prejšnjem mandatu člani UO, se gotovo spomnijo, da je novo vodstvo društva sprejelo imenovanje samo pod dokaj nenavadnim pogojem, da mu ne bo treba organizirati mednarodnega didaktičnega kolokvija. Pogovori, ki jih je pred leti v imenu društva vodil akademik dr. Gantar, so bili spomladi 1999 ob nastopu našega UO na stopnji, ko se je bilo treba dokončno odločiti, ali bomo kolokvij organizirali, in odločitev sporočiti v Belgijo mednarodnemu biroju, ki ga vodi dr. Freddy Decreus. Čeprav nas je bil mednarodni biro pripravljen sprejeti medse, smo morali njegovo ponudbo zavrniti iz razlogov, ki so se, tako menimo, do danes pokazali za upravičene. Dopisi, ki smo si jih izmenjavali, so se sčasoma spremenili v prava pravcata pogajanja o pogojih za sprejem. Prvi pogojje.bil nedvomno organizacija didaktičnega kolokvija. Ker smo se zavedali, da se taka priložnost ne ponudi vsak dan, smo si prizadevali do- seči kompromis, po katerem bi lahko vstopili, a kolokvija ne bi bilo treba organizirati takoj. Mednarodni biro ni bil pripravljen popustiti, še več: pravila, ki so nam bila predstavljena, so predvidevala, da priredimo kolokvij lege artis, da torej pokrijemo stroške za prenočišče in prevoz članom biroja in vabljenim predavateljem. Ko smo člani društvenega vodstva te pogoje preračunavali $\mathrm{v}$ številke in jih seštevali, so se nam pod svinčnikom desettisoči hitro spreminjali v stotisoče in stotisoči v milijone. Vsota, do katere smo prišli - a tudi ta še zdaleč ni bila dokončna - je presegla dva milijona tolarjev in je bila tolikšna, da je društvo ne bi moglo zagotoviti vnaprej. $Z$ vec strani so nam sicer obljubili podporo - tukaj si je veliko prizadevala zlasti članica UO Katja Pavlič Škerjanc, a bridke izkušnje, ki jih imamo od drugod, nas učijo, da se na obljube ni dobro zanašati, če niso zapisane na papirju in podpisane.

FIEC. V najlepšem redu so bili odnosi $z$ mednarodnim združenjem za klasične študije FIEC (Fédération internationale des études classiques). Redno smo plačevali članarino, odgovarjali na dopise, ki so nam jih pošiljali, a žal nismo poslali nobenega predstavnika na kongres, ki je bil lani poleti v Kavali v Grčiji. Upam, da bo lahko na prihodnji kongres (predvidoma bo v Švici) vendarle lahko šel tudi kdo iz našega društva. Skupaj z drugimi evropskimi društvi smo podprli protest proti finančnemu zapostavljanju klasičnih študij s strani Evropske skupnosti, ki ga je sestavil Francisco Adrados, predsed- 
nik španskega združenja za klasične študije.

Eurosophia. Sredi lanskega leta smo dobil dopis, v katerem nam je bilo ponujeno sodelovanje $v$ mednarodni zvezi klasičnih filologov Eurosophia. Zveza je nastala iz nekdanjega združenja francoskih univerzitetnih profesorjev klasičnih jezikov, predseduje ji J.-P. Levet, profesor na univerzi v Grenoblu. Ponudbo smo z veseljem sprejeli in se včlanili. Upamo, da bomo lahko kmalu izkoristili njihovo ponudbo, da predstavimo pouk klasičnih jezikov $\mathrm{v}$ Sloveniji v njihovem biltenu, ki izhaja v tiskani obliki in kot spletna stran. Pred kratkim je bilo to obljubljeno za podatke o pouku latinščine in grščine na naših univerzah, torej podatke, ki ste jih pomagali zbirati tisti člani druš- tva, ki sodelujete v diskusijski skupini Agor@, zato nestrpno čakamo. Mednarodnega posvetovanja o pouku klasičnih jezikov, ki je potekalo v začetku julija 2000 v Trstu, se je kot predstavnica društva udeležila mag. Barbara Zlobec. Obširno poročilo o posvetovanju je objavila v drugi številki III. letnika revije Keria.

\section{ZAHVALE}

Dela je bilo veliko, zahtevalo je veliko časa in truda. Za pomoč se poleg tistih, ki so bili omenjeni že v poročilu, za vse skupaj in počez najiskreneje zahvaljujem še: podpredsedniku društva mag. Branetu Senegačniku, tajniku društva mag. Mateju Hriberšku, blagajniku dr. Marku Marinčiču in predsednici študentske sekcije Nini Vuk.

Matjaž Babǐ̌ predsednik društva

\section{Poročilo študentske sekcije DAHŠ Slovenije za leti 1999-2000}

Študentska sekcija DAHŠ je v zadnjih dveh študijskih letih ob finančni in duhovni podpori DAHŠ izpeljala kar nekaj svojih načrtov. V študijskem letu 1999/2000 je deveterica študentov na pobudo Neže Vilhelm in Nade Grošelj pripravila izbor grških in latinskih epigramov različnih antičnih avtorjev v slovenskem prevodu ter ga prvič predstavila v začetku leta 2000 na večeru antičnih epigramov na Gimnaziji Poljane. Večer antičnih epigramov, $h$ kateremu je David Movrin dodal pogovor z Žarkom Petanom in Brane- tom Senegačnikom o pomenu in vlogi satirika v javnem življenju v antiki in danes, je drugič navdušil občinstvo v Mali Drami februarja istega leta, tretjič pa še jeseni 2000 , ko se je skupina nastopajočih odzvala vabilu Barbare Zlobec in epigrame približala dijakom Slovenske klasične gimnazije $v$ Trstu.

Pod idejnim vodstvom Andreje Inkret in Jere Ivanc je v letu $2000 \mathrm{za}-$ čelo delovati gledališče Théatron. Prvič se je predstavilo maja $2000 \mathrm{z}$ uprizoritvijo Lizistrate na Prešernovem trgu ob manifestaciji ISH, delo pa je nadaljevalo z Antigono, ki je bila premierno uprizorjena junija 2000 v KUD Franc Kotar v Trzinu in 